\title{
Socio-Environmental Survey of two ecologically important hamlets of North Bengal, India
}

\author{
Sayan Bhattacharya ${ }^{1,3, *}$, Arkajyoti Shome ${ }^{2}$, Subrato Sarkar ${ }^{1}$, Debayan Purkait ${ }^{2}$, \\ Uday Chand Ghosh ${ }^{3}$ \\ ${ }^{1}$ Department of Environmental Studies, Rabindra Bharati University, Kolkata, India \\ ${ }^{2}$ Department of Environmental Science, Asutosh College, Kolkata, India \\ ${ }^{3}$ Department of Chemistry, Presidency University, Kolkata, India \\ *E-mail address: sayan_evs@yahoo.co.in , sayan.evs@gmail.com
}

\begin{abstract}
Lava is a small hamlet situated $34 \mathrm{~km}$. east of the Kalimpong subdivision in Darjeeling district of the state of West Bengal, India. Rishyap/Rishop, which nestles amidst the hidden hills of Neora Valley is around $9 \mathrm{~km}$. from Lava. The forest of Neora Valley is very close to Lava and is an excellent place of Indian biodiversity, which spreads over an area of $88 \mathrm{~km}^{2}$. The main objective of the present research work was to construct the social, environmental, cultural and economic framework of the Lava and Rishop area and to highlight the proposals for sustainable management policies of those ecologically sensitive zones. The study was done in April, 2014 by visiting Lava, Rishop and Neora Valley and the information was gathered through field survey and direct contact with common people and authorized centers of the regions. Surveys on the agriculture, horticulture, livestock, water management, education, culture, health, waste management, transport and biodiversity were done in these areas. Lava, Rishop and the Neora valley areas have become the prominent tourist spots of West Bengal for pleasure trips, biological and geographical excursions and medical research works. In spite of getting so much attention in the recent time, the areas are not adequately developed. There is an urgent need for implementing sustainable management systems in the areas for the betterment of the socio-environmental structures. Some of the possible management strategies have been suggested for maintaining the social, environmental, economic and ecological balance of the region.
\end{abstract}

Keywords: Lava; Rishop; Neora Valley; Forest; Environment; Survey

\section{INTRODUCTION}

Forest cover in hills is essential to maintain environmental, economic and ecological balances. North Bengal accounts for 3,086 sq km (26\%) of the $11,876 \mathrm{sq} \mathrm{km}$ area of classified forests in the state, and for nearly 5,000 sq km (40\%) of all land under tree cover. 
The most forested areas are located in Darjeeling and Jalpaiguri, which have 2,994 sq $\mathrm{km}$ of classified forests and 4,614 sq km of forested land under all forms of ownership [1].

Lava $\left(27^{\circ} 5^{\prime} 4^{\prime \prime} \mathrm{N} 88^{\circ} 39^{\prime} 57^{\prime \prime} \mathrm{E}\right)$ is a small hamlet situated $34 \mathrm{~km}$. east of the Kalimpong subdivision $\left(27.06^{\circ} \mathrm{N}, 88.47^{\circ} \mathrm{E}\right)$ in Darjeeling district $\left(27.3^{\circ} \mathrm{N}, 88.16^{\circ} \mathrm{E}\right)$ of the state of West Bengal, India. Lava is situated at an altitude of 7,016 feet $(2,138 \mathrm{~m})$ in the foot-hill of the Himalayas. In winter, occasionally temperature comes below $0{ }^{\circ} \mathrm{C}$; in summer maximum temperature crosses $20{ }^{\circ} \mathrm{C}$. Snowfall is common between November and February [2]. Monsoon starts from May to middle of October. The average annual rainfall of Lava is 635 $\mathrm{cm}$. Lava is the gateway of Neora Valley National Park, a virgin, unexplored terrain in the Himalayas. The route to Lava is scenic with the change in vegetation from tropical deciduous to the wet alpine trees of fir, pine and birch. The verdant forest is excellent spot for picnic, trekking and bird-watching. Lava has now become a favorite tourist destination for people living on the coast of West Bengal, and tourism has become the most important source of living for the inhabitants. The nearest town of Lava is Kalimpong (around $30 \mathrm{~km}$.), nearest railway station is New Jalpaiguri (around $120 \mathrm{~km}$.) and nearest airport is Bagdorga $(125 \mathrm{~km}$.) [3]. The population in Lava is comprised of around 1200-1300 people. The local people economically dependent on tourism and agriculture.

Another beautiful small hamlet Rishyap/Rishop, which nestles amidst the hidden hills of Neora Valley is around $9 \mathrm{~km}$. from Lava, or one can avail the beautiful trekking road which is around $4 \mathrm{~km}$. long. An excellent view of Kanchenjunga from 'Tiffin Dara' in Rishop attracts tourists to this place. The deep silent forest of Pine, Birch, Fir and Orchids with soothing path and the spectacular view of snowcapped Kanchenjunga are the main attractions of Rishyap [4].

Neora Valley National Park (NVNP) in the Kalimpong Hills, Darjeeling District, having a wide range of altitudinal variations (183-3,200 m) and climatic conditions and forming an ecological junction with Sikkim and Bhutan, is the last virgin wilderness in West Bengal. The forest is situated between the $26.52^{\circ} \mathrm{N}$ and $27.7^{\circ} \mathrm{N}$ and $80.45^{\circ} \mathrm{E}$ to $80.55^{\circ} \mathrm{E}$ [5]. It is one of the oldest (1881) reserve forests in India. The forest is around $12 \mathrm{~km}$. from Lava. It was notified as a protected area of national importance in April 1986 and finally gazetted in December 1992. In May 2009, Neora Valley was also been included in the shortlist of World Heritage sites [13].

The main objective of the present research work was to construct the social, environmental, cultural and economic framework of the Lava and Rishop area and to highlight the proposals for sustainable management policies of those ecologically sensitive zones.

\section{METHODS OF THE SURVEY WORK}

The study was done in April, 2014 by visiting Lava and Rishop and the primary data were gathered through field survey and direct contact with common people and authorized centers of the region. Information on agricultural activities is collected from the local villagers. Report on the silviculture unit (hills) of Lava was prepared based on the information displayed there and the names of the chemicals used in the cultivation were collected from the chemical stocks kept in the unit. Information regarding the transport system was collected from the local transport office and syndicate. Religious and social festival information was collected from the local people and from the Buddhist monastery. Health and education information was collected from the monastery, local primary and high 
school and the local sub health centre. Information on environmental activities like using rainwater harvesting structures and waste management policies is collected through surveys in the villages and from the local hotels situated in Lava and Rishop. Biodiversity was observed by visiting the Neora Valley National Park and the Neora Valley Nature Interpretation Centre situated at Lava. Pictorial documentation was done in every phase of study.

\section{AGRICULTURE, HORTICULTURE AND LIVESTOCK}

In Lava, the common cultivable edible plants are rice, ginger, cauliflower, cabbage, beans, radish etc. In Rishop, the common edible plants are maize, green peas, potatoes, cauliflower, cabbage, tomato, garlic, coriander etc. In both regions, organic cultivation is done by using cowdung and jungle soil (rich in organic matter and micronutrients). In Rishop, no synthetic fertilizers or pesticides are used in cultivation. Large Cardamom (Amomum subulatum) is cultivated in Rishop, however, in recent times, the production has been severely affected by the shortage of water (according to local reports). Some houses in Lava and most of the houses in Rishop have cultivable lands adjacent to the houses and farming is done there. In Rishop, many medicinal plant varieties are cultivated in the villages as well. Agricultural production is one of the main economic sources of the people in Lava and Rishop. They used to sell the foods in the markets after production. In Rishop, sericulture is practiced. In the village houses of Rishop, honey is produced and the people earn by selling the honey in the markets.

Lava Research Station, Silviculture (Hills) was established by the Government of West Bengal for the practice of controlling the establishment, growth, composition, health, and quality of forest plants of economic importance. One of the main objectives of this kind of unit is to improve the growing stock of forest in hilly areas of North Bengal [6]. Various steps are taken here for the tree improvement, which include the selection, nursery work and plantations. Clonal propagation is an important part of Tree Improvement Programme in the silviculture unit. It is done by grafting and cutting in the specially designed mist chamber (permanent and temporary tunnels) and glass houses in all the nurseries of silviculture division [6]. In the mist chambers, the clonal propagation work is carried out throughout the year (Figure 1). In the last 3 years, efforts are being made to improve the nursery techniques in order to increase the efficiency so as to get improved quality of seedlings in short times [6]. The following methods are being introduced as modern nursery practice:

1. Making of compost and proper soil mixture.

2. Use of root trainer.

3. Installation of self root pruning bed.

4. Irrigation by overhead spraying system.

5. Agronet as a shade.

With these newly introduced techniques, the nursery time of most of the species particularly in the hill areas have reduced to almost half of its normal time that used to take place earlier [6]. 
The clone (ramit) which are prepared in the nurseries are utilized in the clonal plantation in all the research stations situated in North Bengal. The clonal plantations have been done in the following forms:

1. Clonal seed orchard.

2. Clonal bank orchard.

3. Clonal multiplication garden and hedge in nursery [6].

The species which are cultured in the Lava silviculture unit are: Rhododendron grande (Local name: Chimal), Rhododendron arboreum (Local name: Lali Guras), Betula alnoides (Local name: Saur), Acer hookeri (Local name: Lal Kapasi), Elaeocarpus sikkimensis (Local name: Bhadrasay), Acer osmastonii (Local name: Kapasi), Castonopsis hystrix (Local name: Patley Katus), Quercus lamellosa (Local name: Buk), Bucklandia populnea (Local name: Pipli), Michelia excelsa (Local name: Rani Champ), Michelia cathcartii (Local name: Titey Champ), Taxus wallichina (Local name: Dhandra salla), Magnolia campbellii (Local name: Ghoge Champ), Nyssa javanica (Local name: Lakh chilowne), Pinus patula (Local name: Pine), Quercus lineata (Local name: Phalat), Betula ainoides (Local name: Saur), Abies densa (Local name: Gobrey salla) etc. Figure 2 shows the silviculture unit of Lava.

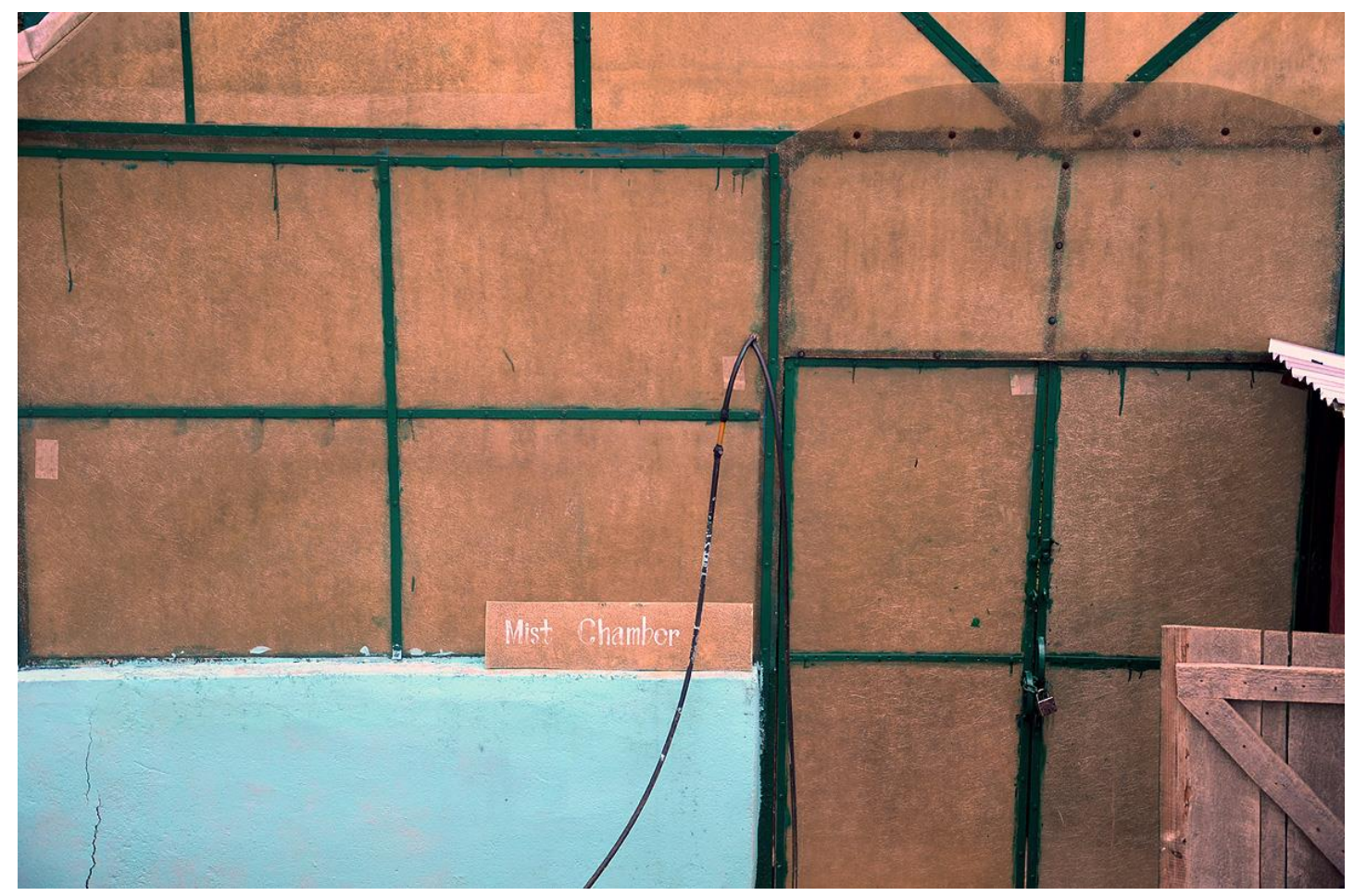

Figure 1. Mist chamber at Lava Silviculture Unit.

Various pesticides and fertilizers are used in the Lava Research Centre, Silviculture (Hills). Cowdung and nutrient rich jungle soil are generally used for the cultivation. The compost is prepared from the jungle soil. Compost chambers are situated beside the horticultural unit, where separate chambers are used for the preparation (Figure 3). 
Several synthetic chemicals are also used for the cultivation in the silviculture unit like: Roodex (Root hormone), Ripcord (Emulsifiable concentrate containing Cypermethrin for insect control), Bavistin (systemic broad spectrum fungicide with protectant and eradicant activities), Gibberellic acid $0.001 \%$ (Plant growth regulator), Tafgor (insecticide, Dimethoate $30 \%$ EC), Biozyme (liquid biofertilizer which can stimulate soil microbes and can increase the availability of soil nutrients and they also play a significant role in defending against soilbased diseases), Tracel (scientifically formulated blends of micronutrients in soluble, crystalline form) etc. Figure 4 shows the pesticides and fertilizers kept at the Lava silviculture unit.

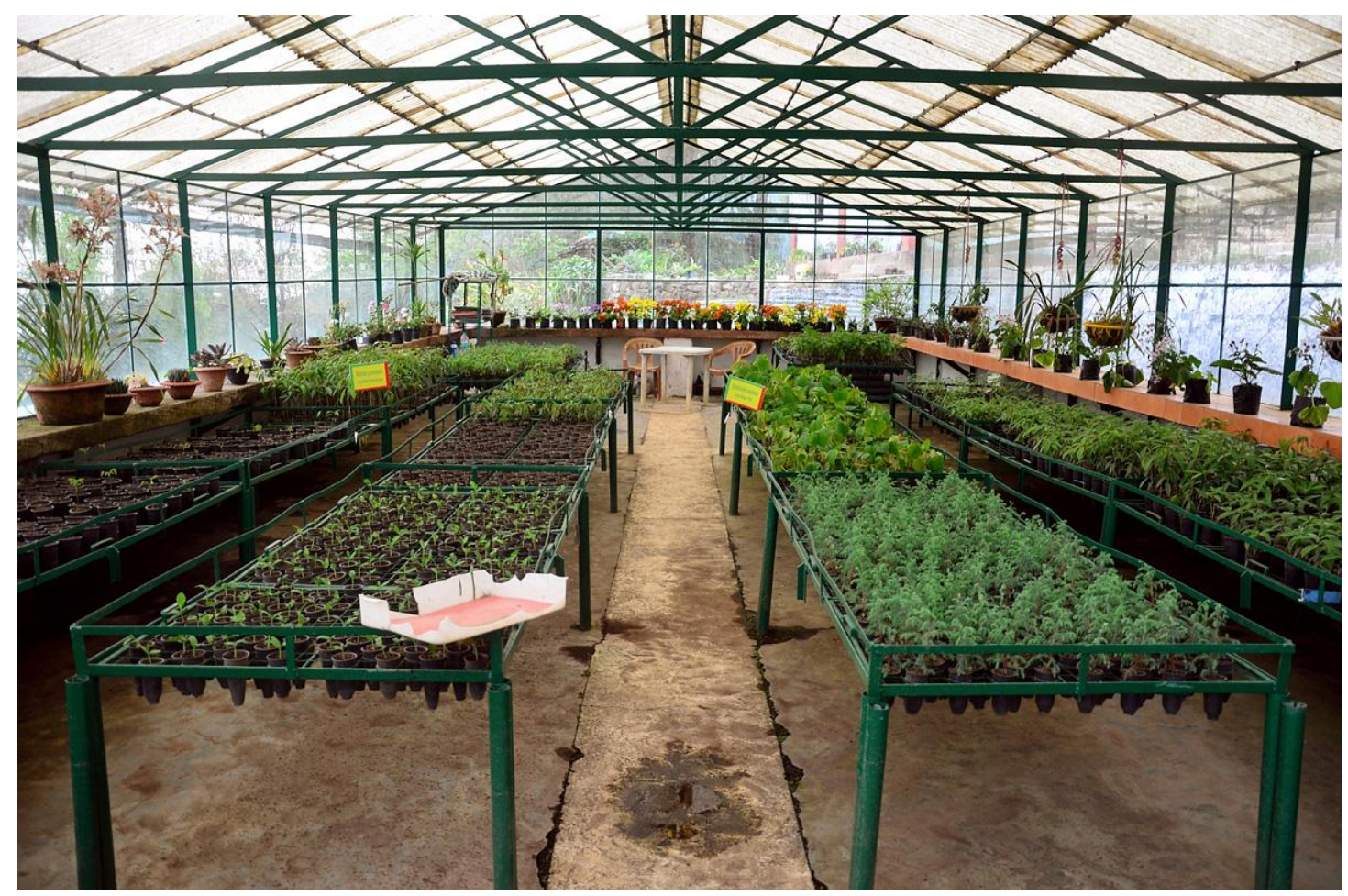

Figure 2. Silviculture Unit (Hills) at Lava.

Several synthetic chemicals are also used for the cultivation in the silviculture unit like: Roodex (Root hormone), Ripcord (Emulsifiable concentrate containing Cypermethrin for insect control), Bavistin (systemic broad spectrum fungicide with protectant and eradicant activities), Gibberellic acid $0.001 \%$ (Plant growth regulator), Tafgor (insecticide, Dimethoate $30 \%$ EC), Biozyme (liquid biofertilizer which can stimulate soil microbes and can increase the availability of soil nutrients and they also play a significant role in defending against soilbased diseases), Tracel (scientifically formulated blends of micronutrients in soluble, crystalline form) etc. Figure 4 shows the pesticides and fertilizers kept at the Lava silviculture unit.

There is also a green house in the Siule village near Rishop, where several varieties of flowers and medicinal plants are preserved. The common livestock in Lava and Rishop are cow, goat and pig. Local poultry farms are found in most of the houses in Rishop. Meat and milk are the main livestock products which are one of the important economic sources. In 2004, a milk chilling plant was established in Lava, from where milk is supplied to Siliguri. 


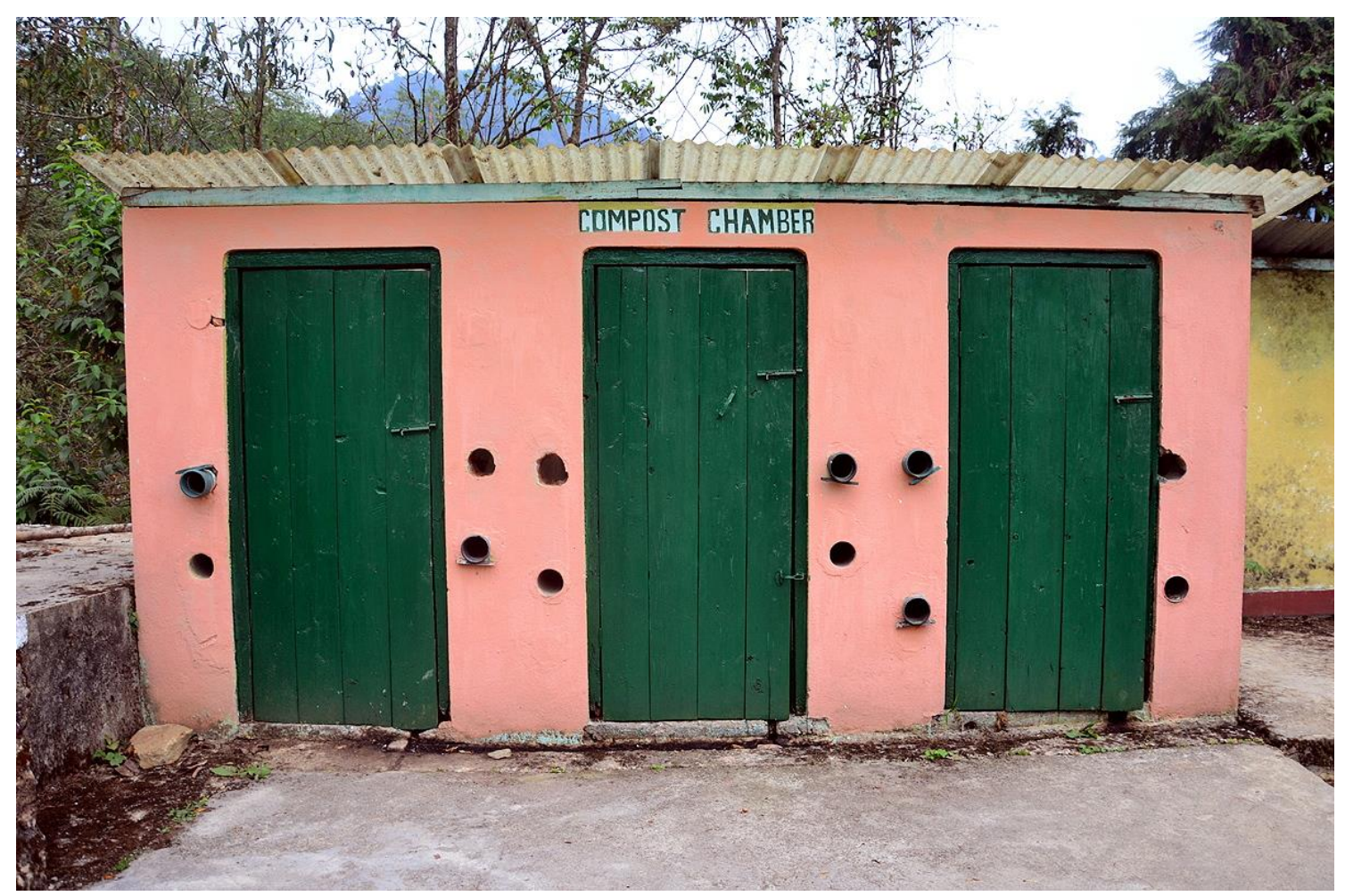

Figure 3. Compost chamber in Silviculture unit at Lava.

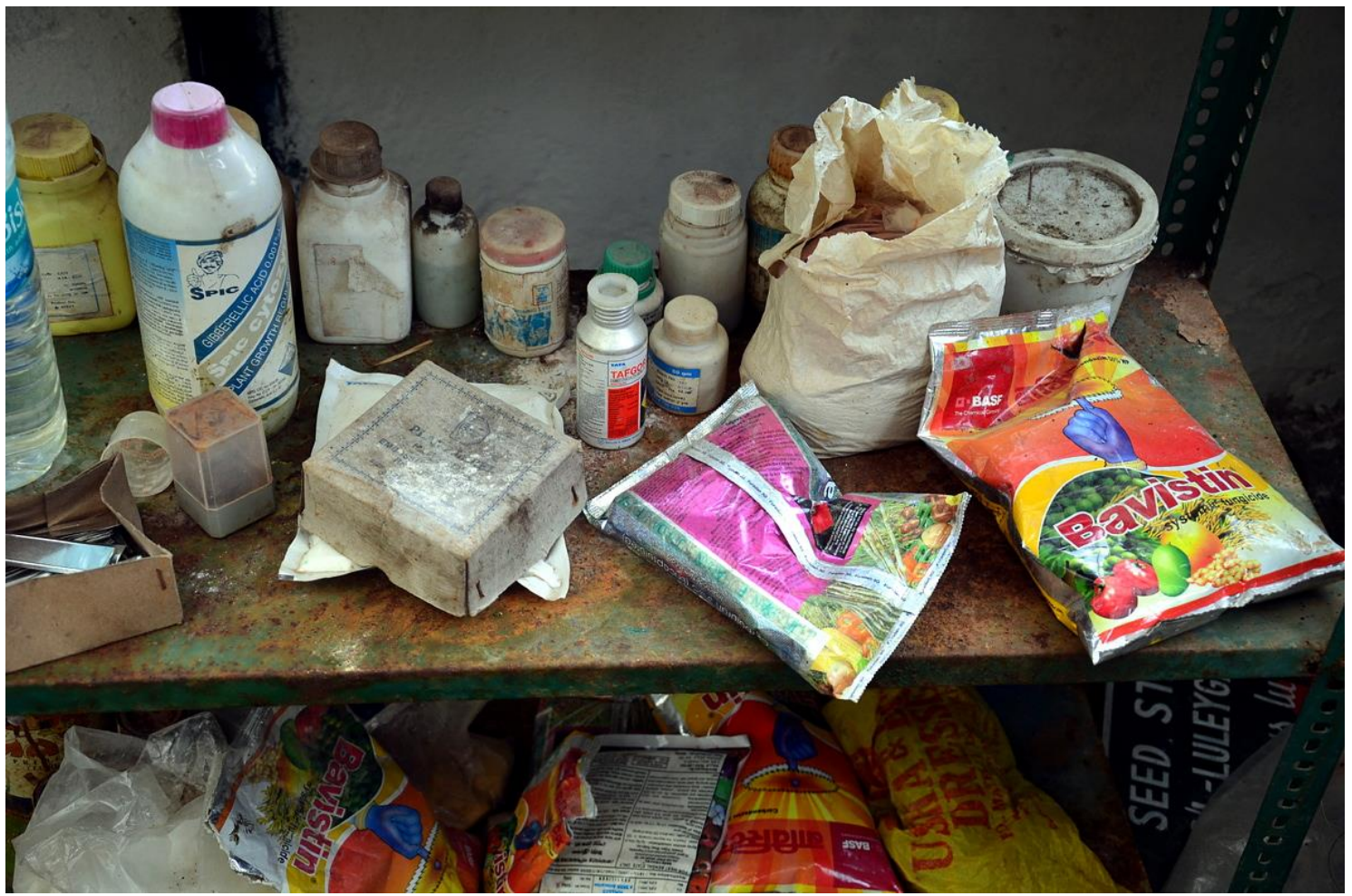

Figure 4. Pesticides and fertilizers used in the Silviculture unit at Lava. 


\section{WATER MANAGEMENT}

The main source of water in Lava is the Neora River situated in the Neora Valley National Park. Long pipelines are constructed from the water source to Lava and water is distributed through networks of pipes in the houses. However, there is periodical water crisis in Rishop, mainly in the dry seasons. 14000 feet long pipe is used for bringing and distributing water in the region. The people of Rishop used to bring water from Lava through vehicles at the rate of 1 rupee (INR) per liter of water.

The roofs of many hotels, resorts and houses of Rishop have aluminium gutters (long, hollow device that is attached to the edges of the roof to catch rain and carry it away from a building) at the corner for collecting rainwater. The roofs have inclined slope, so that water flows easily in the gutter. The rainwater falling on the roof top can be collected through these gutter channels. Pipes are connected with the gutters through which water can be collected in the cisterns and containers.

The collected rainwater is used for bathing, washing and irrigation purpose. For drinking purpose, the people depend on the supplied water. In Lava, similar kind of rainwater harvesting structures are found in some houses, however, they are fewer in number due to adequate supply of water in Lava. Figure $5 \mathrm{a}$ and $5 \mathrm{~b}$ show the roof top rainwater harvesting at Rishop.

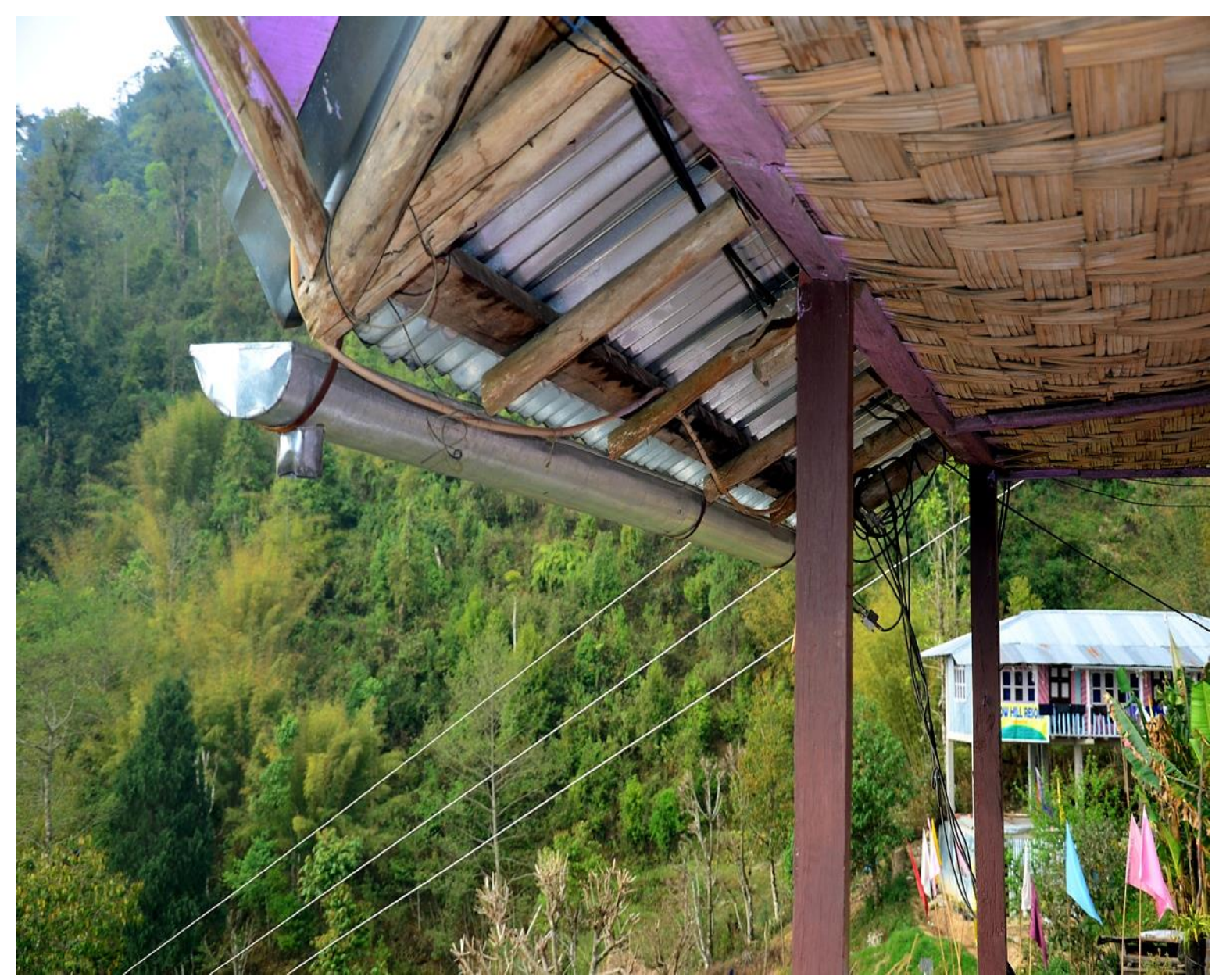

Figure 5(a). Roof top rainwater harvesting at Rishop. 


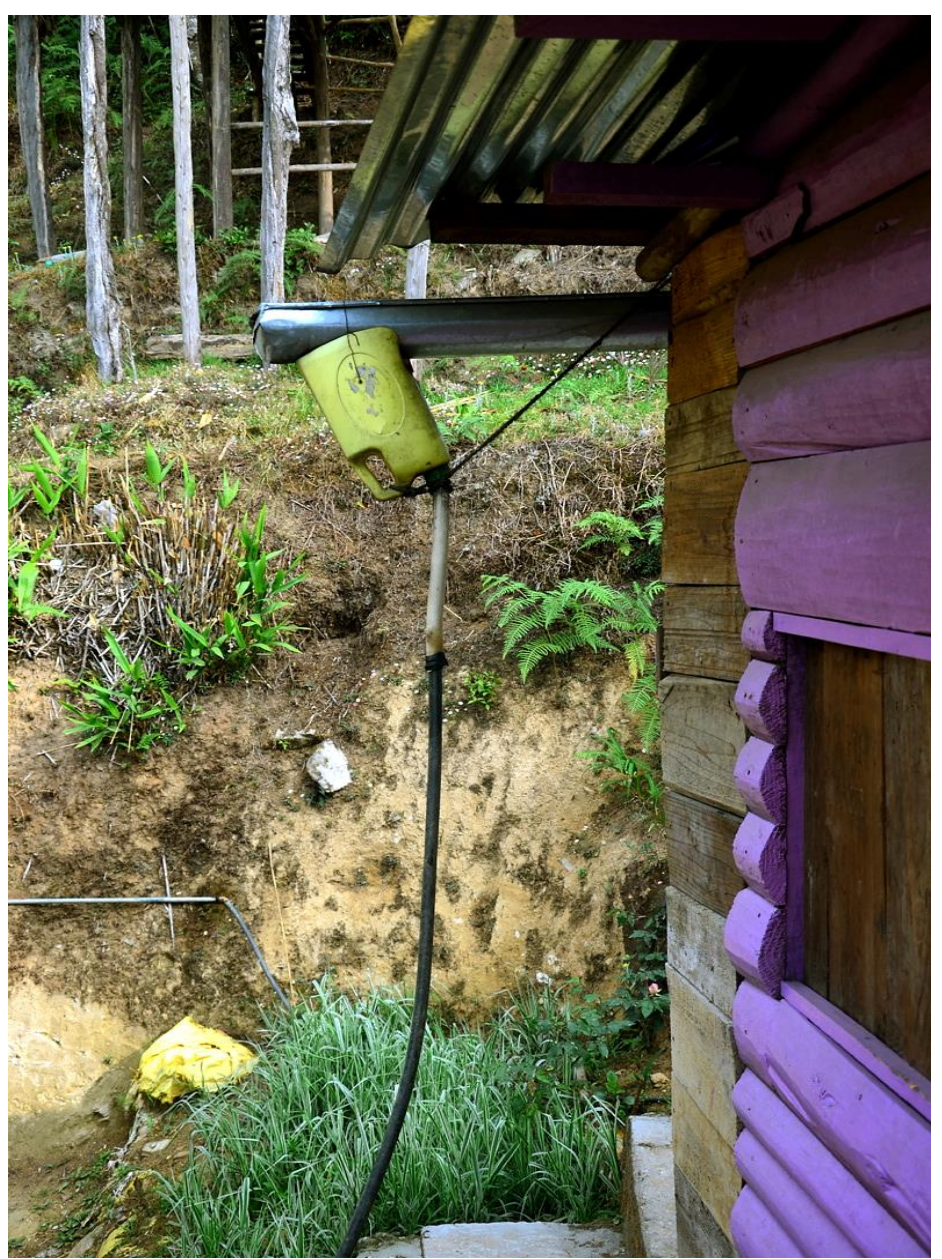

Figure 5(b). Roof top rainwater harvesting at Rishop.

\section{EDUCATION, CULTURE AND HEALTH}

There are two schools in Lava: Lava Primary School and Lava High School (Figure 6). The number of students in these two schools is approximately 600-700. In Rishop, there is one Primary School and one Nursery school. For higher education, the inhabitants of Lava and Rishop used to go Kalimpong and Siliguri. There is one public library in Lava, which was established in 2009. There is one community hall in Lava (established in 2003), where several cultural programmes are conducted. Usually the school students perform in the hall during special occasions.

A Buddhist monastery (Lava Jamgyong Kongtrul Monastery) is present on one of the hills of Lava. The monastery was established in 1989. The founder of the monastery was Jamgyong Kongtrul. There are around 130 students in the monastery and 5 teachers. Thirteen years of curriculum is there and the syllabus is mainly based on Buddhist philosophy and history. Besides, English is also taught as an optional subject. After completing the 13 years course, the students become the "Acharyas". The Acharyas then get involved in teaching, administrative works and social works in the villages. There are two prayer halls and one meditation hall in the monastery. 


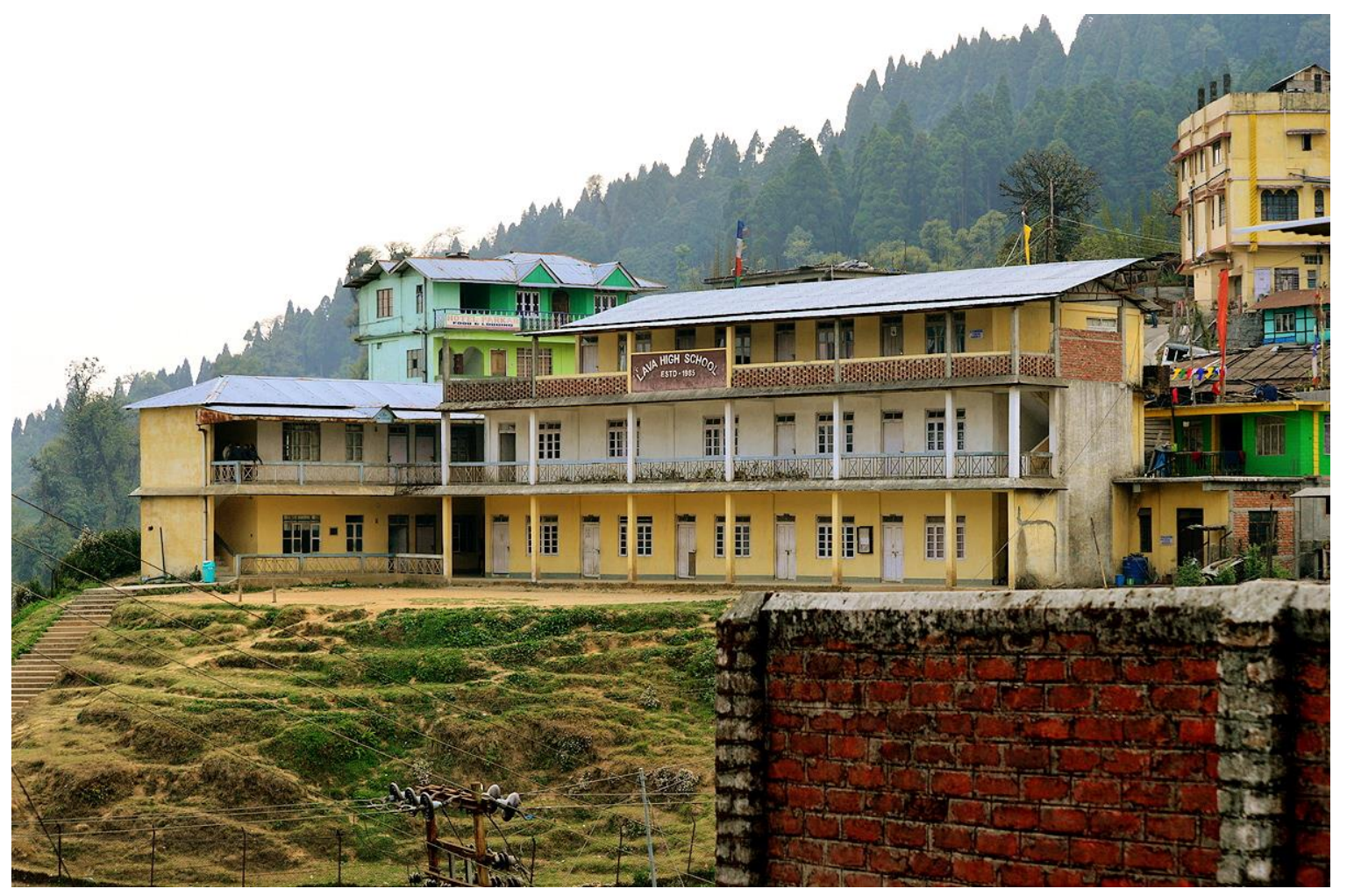

Figure 6. Lava High School, established in 1985.

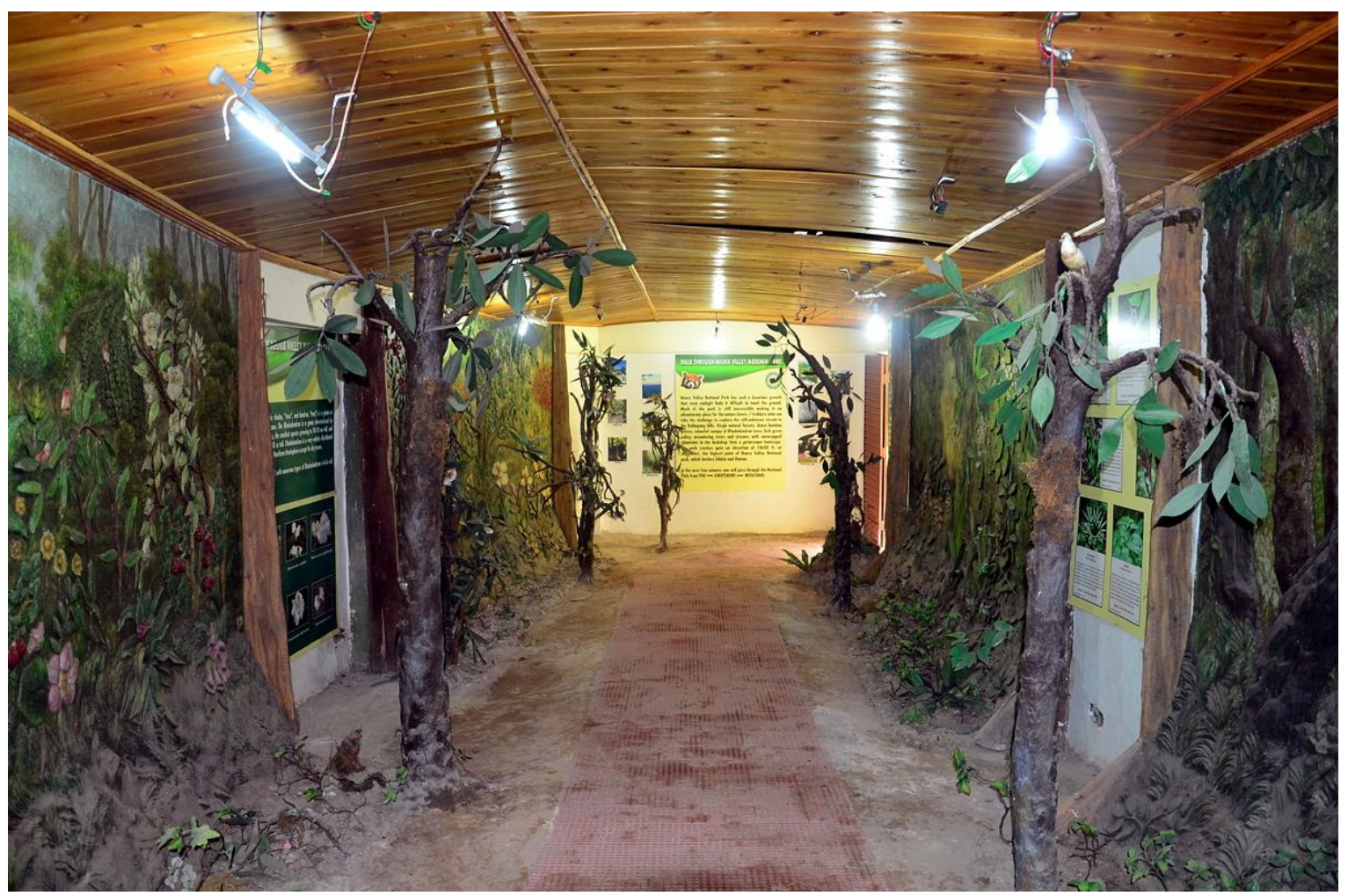

Figure 7. Neora Valley Nature Interpretation Centre at Lava. 
Neora Valley Nature Interpretation Centre is situated at Lava which displays the environment of the Neora Valley National Park in the form of models, photographs, stuffed birds and animals. It also has a good display of orchids and other flowers. Several posters with beautiful photographs lucidly describe the biodiversity of Neora Valley in the interpretation centre. Figure 7 shows the Nature Interpretation Centre at Lava.

The main festivals of Lava are Durga Puja and Losar. Losar is the Buddhist festival ("Losar" in Tibetan language means New Year), which is celebrated for 15 days, however, the main celebration occurs in the first three days. In Rishop, the main festivals are Dasara, Diwali and Losar.

Interestingly, there is no specific medicine shop in Lava and Rishop. People used to go to Kalimpong and Siliguri for treatment purpose. Recently, a sub health centre has been established in Lava in November, 2013, which was organized by "Lava Samrakshan Samity". The centre is open on Monday, Tuesday and Friday.

There is one sister who used to look after the patient, and one doctor (who visits the centre once in a month). They mainly deal with child diseases and maternity problems. In Rishop, there is a nearby sub health centre in the Ladam village, where similar pattern of health care system is followed.

\section{WASTE MANAGEMENT}

In Lava, the people used to burn the waste materials in a specific empty place once in a week. In Rishop, every hotel has their own burning place where they used to burn all the waste materials once in a week. The people of Rishop used to bring the fuel wood from the forest area after taking permission from the government. Usually the rotten and low quality woods are used for burning purpose. They used to store the wood in the storehouses after bringing them from the forests. "No plastic zone" is marked at the Nature Interpretation center and the Zero Point of Neora Valley National Park.

The students and teachers of Lava Monastery used to collect waste materials from the nearby villages twice a year and dispose the wastes properly.

\section{TRANSPORT AND CONNECTIVITY}

Lava is well connected with other adjoining areas of North Bengal. In public transports, there are two small buses in the morning which connect Lava with Siliguri. Additionally, there is one car which goes o Siliguri from Lava in the morning, carrying around 14-15 passengers on sharing basis. There are also sufficient numbers of private cars which can be hired for going different parts of North Bengal.

There is no bus service in Rishop. However, the transport syndicate in Rishop provides cars which can be hired for going Lava and other places of North Bengal. Lava and Rishop are connected with places of Bengal and Sikkim like Siliguri, New Jalpaiguri, Gorumara forest, Lataguri forest, Murti (dooars area), Hollong, Bagdogra, Darjeeling, Malbazar, Odlabari, Tinchuley, Gangtok, Pelling, Mirik, Ravangla, Gorubathan, Kalimpong, Jorethang, Pedong, Rangpoo, Kersiong etc. Cars are the most popular mode of transport, specially in case of sightseeing purpose. 


\section{BIODIVERSITY}

Lava and Rishop are very famous for the varieties of medicinal plants and the bird species found there. Neora Valley National Park (Figure 8) is a unique and ecologically important forest area as it includes a relatively inaccessible patch of late successional forest with rich diversity and a wide range of environmental gradients. The forest of Neora Valley is very close to Lava and is an excellent place of Indian biodiversity. It spreads over an area of $88 \mathrm{~km}^{2}$.

The forest types are mainly tropical, sub-tropical, temperate and sub-temperate. Neora Valley, along with its adjoining forests of Kalimpong Forest Division, is also an important ecological corridor in Eastern Himalayas for movement of long-ranging animals to and from other contiguous protected areas in North Bengal [7].

The forest exhibits a rich variety of habitats, as the area comprises the catchment and watershed of the Neora River, which is fed by nine main streams and sixteen subsidiary streams. Four habitat types are recognized in NVNP, namely: i) Subtropical Mixed Broadleaf Forest; ii) Lower Temperate Evergreen Forest; iii) Upper Temperate Mixed Broadleaf Forest; and iv) Rhododendron Forest [7]. The national park provides an opportunity for research in the various fields like behavioural ecology, habitat ecology, reproductive biology, genetics, immunology and medical research.

The forest contains approximately 680 species of angiosperms, 23 species of pteridophytes, 276 species of insects, 38 species of other invertebrates, 308 species of birds and 33 species of mammals [7]. Approximately $20 \%$ of the total species found in Neora Valley are extremely rare and many of those face the threats of extinction. Some of the species of Neora Valley National Park are mentioned below:

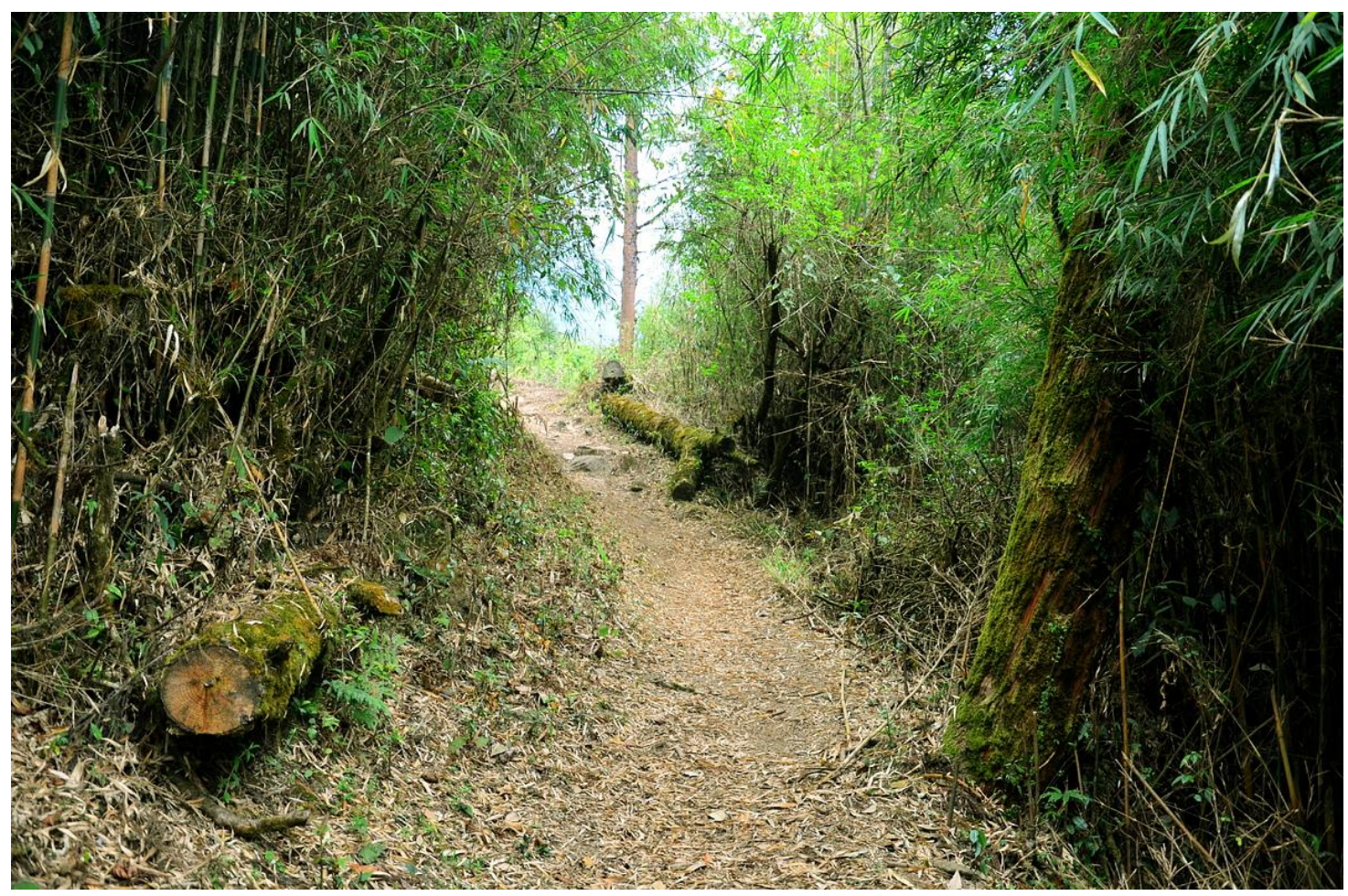

Figure 8. Neora Valley National Park. 


\section{1. Flora}

Some of the important medicinal plants found in the Neora Valley are listed below [5]. Some of these examples are exhibited in the Neora Valley Nature Interpretation Centre (Lava) with descriptions and illustrations.

\begin{tabular}{|c|c|c|}
\hline Common Names & Scientific Names & Uses \\
\hline Chinese Pepper & Litsea Citrata & $\begin{array}{l}\text { Antidepressant, antiseptic, } \\
\text { insecticide; helpful in heart } \\
\text { diseases, bronchitis and asthma. }\end{array}$ \\
\hline Manjistha & Rubia cordifolia & $\begin{array}{l}\text { Detoxify blood, dissolve } \\
\text { obstructions in blood flow. }\end{array}$ \\
\hline Herbaceous Woodlander & Smilacina oleracea & Root extract can cure fractures. \\
\hline Chirayata & Swertia chirata & $\begin{array}{c}\text { Drug for intermittent fevers, } \\
\text { skin diseases, bronchial asthma. }\end{array}$ \\
\hline Indian snakeroot/Sarpagandha & Rouwolfia serpentine & $\begin{array}{l}\text { Drug for high blood pressure } \\
\text { and schizophrenia. }\end{array}$ \\
\hline Ground pines/creeping cedar & Lycopodium sp. & $\begin{array}{l}\text { For treatment of disorders of } \\
\text { the locomotor system, skin, } \\
\text { liver and bile, kidneys and } \\
\text { urinary tract infections. }\end{array}$ \\
\hline Himalayan ginseng & Panax pseudoginseng & $\begin{array}{c}\text { Antibacterial, anti- } \\
\text { inflammatory, antiseptic, } \\
\text { hypoglycemic. }\end{array}$ \\
\hline Lekh Mayal (local name) & Sorbus cuspidata & $\begin{array}{l}\text { Can stimulate respiration and } \\
\text { improve digestion. Also } \\
\text { claimed to be effective in } \\
\text { cancer treatment. }\end{array}$ \\
\hline Shilapushpa & Didymocarpus pedicellata & $\begin{array}{l}\text { Prevents the formation of } \\
\text { urinary stones, antimicrobial } \\
\text { property. }\end{array}$ \\
\hline
\end{tabular}

Neora Valley is very rich with several Rhododendron species like Rhododendron arboreum, $R$. falconeri, $R$. barbatum, $R$. dalhousiae, $R$. grande, $R$. triflorum etc. Other noticeable plant species are Acer cambellii, Artocarpus chaplasa, Alianthus grandis, Castanopsis indica, Michelia champaca, Abies densa etc. There are several bryophyte species are found, like Funaria sp., Hookeria sp., Asterella sp. etc. High diversity of orchids are found among which species of Acampe, Aerides, Bulbophyllum, Calanthe, Dendrobium, Eria, Thunia etc. are noticeable. Wild flowers include Touch Me Not (Mimosa putica), Railway Glory (Ipomoea cairica), English Primrose (Primula vulgaris), Wild Musk Melon (Cucumis melo) etc [5].

\section{2. Fauna}

There are 276 species of insects (118 genera, 89 families and 17 orders) and 38 species of other invertebrates (mollusks, arthropods and annelids), including 6 species of leeches in Neora Valley National Park [8,9]. 
The Neora valley is richly blessed with a medley of beautiful butterflies like Knight (Labadea Martha), Redbeast (Papilo alcmenor), Tailed Red Forester (Lethe sinorix), Yellow Orange Tip (Ixias pyrene), Indian Tortoise Shell (Aglais cashmirensis), Painted Lady (Cynthia cardui), Golden Sapphire (Heliophorus brahma), Bath White (Pontia daplidice), Tiger Brown (Orinoma damaris) etc. The Neora river, which runs for about $57.6 \mathrm{~km}$. from north to south, is drained by 9 major streams and 16 subsidiary streams. This part of the Eastern Himalaya has a greater diversity of coldwater fishes than the other parts of the Himalayas. Examples of fishes are Balsohani (Nangra punctata), Goni (Labeo gonius), Hara (Hara jordoni), Lohari (Garra annandalei), Bumble bee (Laguvia shawi) etc [5].

Amphibians include Common Tree Frog (Polypedates teraiensis), Himalayan Frog (Bufo himalayanus), Himalayan Bull Frog (Paa leibigii), Twin Spotted Tree Frog (Rhacophorus bipunctatus) etc [5]. Reptiles like Flat-backed Mountain Lizard (Japalura planidorsata), Indian Garden Lizard (Calotes versicolor), Asian Glass Lizard (Ophisaurus gracilis), Flat Tailed Gecko (Hemidactylus garnoti), Spectacled Cobra (Naja naja), Common Wolf Snake (Lycodon aulicus), King Cobra (Ophiophagus hannah), Indian Rat Snake (Ptyas mucosa) etc. are found in the Neora Valley forest area [5]. Neora Valley is considered as the paradise of the bird watchers. Among approximately 300 bird species found in Neora Valley, 7 are "globally threatened" and 2 are "near threatened", 12 species belong to the Red Data Book list [7]. The Red Data Book enlisted species are Greater Spotted Eagle (Aquila clanga), Blue Fronted Robin (Cinclidum frontale), Broad-billed Warbler (Tickellia hodgsoni), Lesser Kestrel (Falco naumanni) etc. The other bird species include Black Eagle (Ictinaetus malayensis), White Tailed Robin (Myiomela leucura), Great Tit (Parus major), Greenbacked Tit (Parus monticolous), Eurasian Tree Sparrow (Passer montanus), Ashy Wood Pigeon (Columba pulchricollis), Brown Parrotbill (Paradoxornis unicolor), Chestnut Thrush (Turdus rubrocanus), Black-throated Sunbird (Aethopyga saturata), Hill Myna (Gracula religiosa), Goldcrest (Regulus regulus) etc [5,7]. We observed and photographed Greenbacked Tit and Eurasian Tree Sparrow, which are showed in Figure 9 and 10.

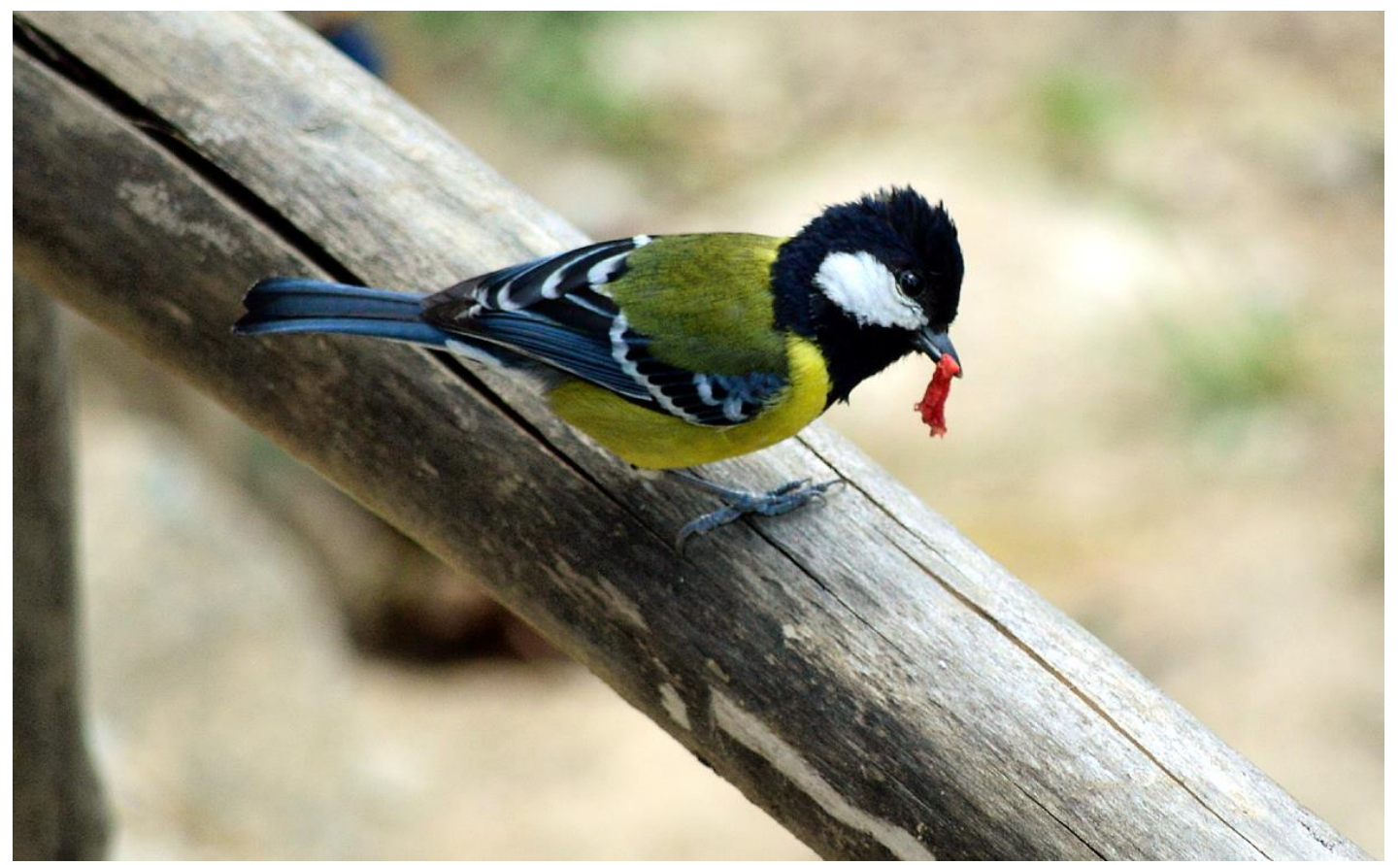

Figure 9. Green-backed Tit at Neora Valley National Park. 


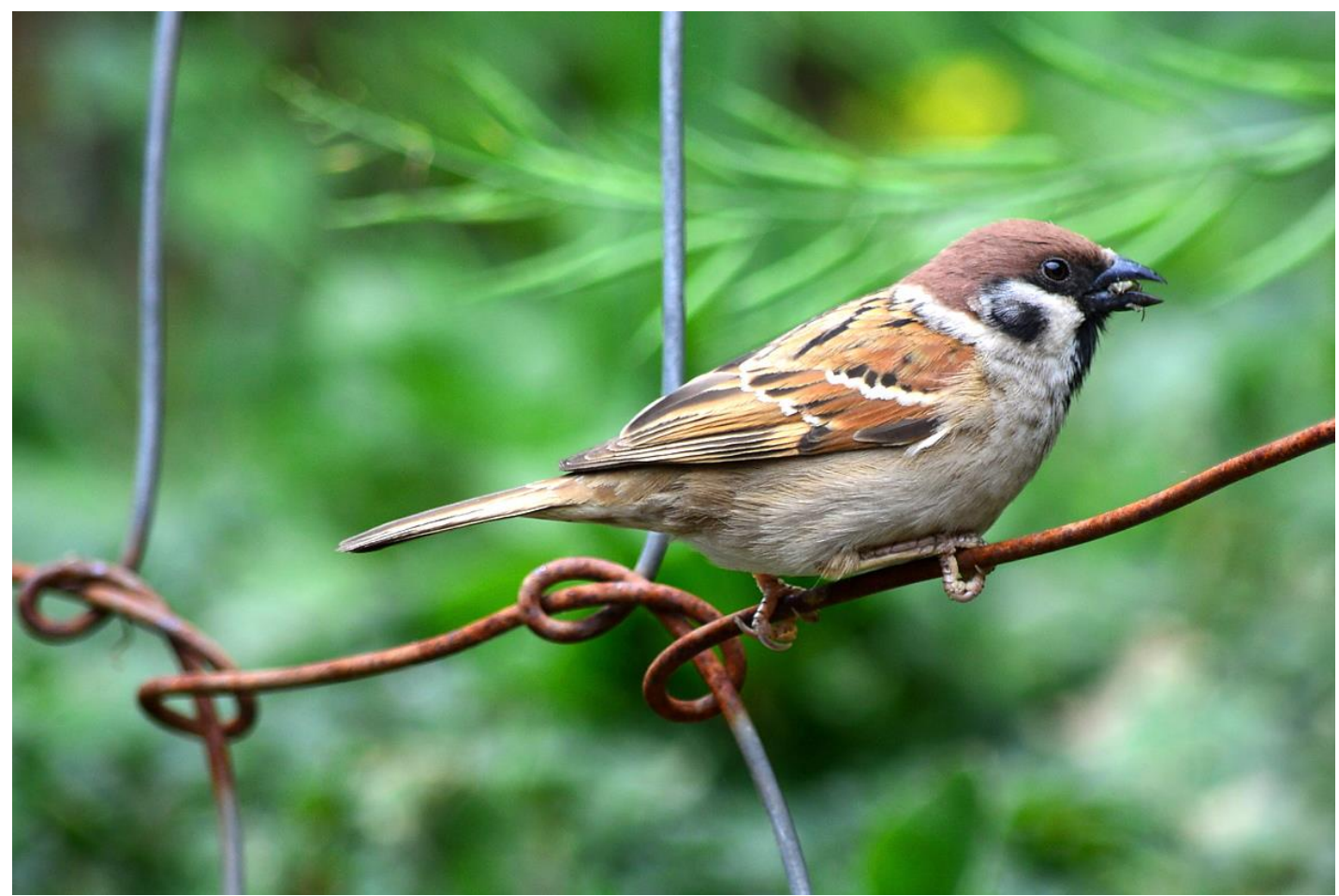

Figure 10. Eurasian Tree Sparrow at Neora Valley National Park.

Neora Valley provides shelter and protection to various species of mammals included in Red Data Book of IUCN and appendices of CITES (Convention on International Trade in Endangered Species of wild flora and fauna). Red Panda (Ailurus fulgens), Gaur (Bos gaurus), Leopard (Panthera paardus), Tiger (Panthera tigris), Asiatic Black Bear (Ursus thibetanus), Red Fox (Vulpes vulpes), Barking Deer (Muntiacus muntjak), Himalayan Palm Civet (Paguma larvata), Marbled Cat (Pardofelis marmorata), Asiatic Wild Dog (Cuon alpines) are significant mammals of Neora Valley [5,7].

Before 1950s, Neora Valley National Park was inaccessible to tourists. In recent times, due to the initiatives of several tourism programmes, the place is a trekking attraction. October to May is considered to be the best time for trekking through the National Park. The forest has varieties of landscapes like the view of snow capped mountains, waterscapes, vegetation landscapes, densely forested and wooded landscapes [5].

\section{CONCLUSIONS}

Lava, Rishop and the Neora valley areas have become the prominent tourist spots of West Bengal for pleasure trips, biological and geographical excursions and medical research works. In spite of getting so much attention in the recent time, the areas are not adequately developed.

There is an urgent need for implementing sustainable management systems in the areas for the betterment of the socio-environmental structures. Some of the implementable management systems are as follows: 
1. The ecotourism spots of Lava and Rishop are least advertised or given adequate publicity. Lack of systematic organization is another constraint of ecotourism in the study area [11]. These issues should be addressed for the effective planning of sustainable ecotourism.

2. For reducing the water crisis in the Rishop area, micro scale rainwater harvesting structures should be installed in the houses. Filtering systems should be provided to the local inhabitants so that they can use the rainwater for drinking purpose after purifying it.

3. Adequate health services should be provided to the local inhabitants of Lava and Rishop. Health centers with sufficient number of doctors and nurses should be established in these areas.

4. Precaution should be taken for reducing the incidents of biopiracy, as these regions are very rich in medicinal plant resources.

5. Large Cardamom (Amomum subulatum) production has been severely affected at Rishop due to water crisis (according to local reports). The issue should be investigated in detail and proper measures should be taken for the conservation of that local species.

6. Local training centers should be established for teaching the local people about the importance of natural resources of Lava, Rishop and Neora Valley. The initiatives of the local people can effectively protect the natural assets of those areas.

7. Portfolio of tourism products should be developed by utilizing its unique ecological assets [11]. As these areas are the attraction for tourists, development of handicrafts made from the forest bioresources could be beneficial for the economic development of the local communities.

8. West Bengal is the cultural capital of India. It has constantly produced thoughts, ideas and events which have brought forth freshness and rejuvenation in the society both in India and the world. The specific components of Cultural Tourism which can be implemented in these areas which can include Fairs and Festivals Tourism, Arts and Crafts Tourism and Village Tourism.

9. Tourism carrying capacity is defined as the maximum number of people that may visit the tourist destination without causing destruction of the physical, economic and socio cultural environment and an unacceptable decrease in the quality of visitors' satisfaction. The carrying capacity assessment and sustainability of tourism in the circuits identified is an important component of the ecotourism study as it will form the basis for resource allocation and future development. The carrying capacity assessment should be done separately for Lava and Rishop, based on city population (resident), population density and tourist population and density (floating population).

10. There is lack of gross knowledge among villagers on the advantages of afforestation in the Hill areas. Specific training and awareness efforts from the Forest Department have to be undertaken to educate people on the drawbacks of deforestation and the long term effects it has on climate.

11. The effects of climate change are more severe in the Himalayas compared to the other regions [14]. Extensive studies on the effects of climate change on Neora Valley National Park should be done, as this zone represents one of the richest biodiversity zones of India. 
12. Like any other protected area in India, Neora Valley National Park also suffers from illegal cattle grazing, firewood collection, encroachment on the fringes and poaching. However, due to inaccessibility and difficult terrain, the biotic pressures are still not very acute. More intense survey works and management practices should be done in the Neora Valley for mitigating the anthropogenic threats.

13. Separate waste collection and disposal system should be operated by the government for safeguarding the sensitive ecosystems of the areas. Effective management design should be done for plastic wastes generated in these areas.

14. The vehicles used in the areas should be monitored regularly so that the vehicular pollution could be checked in the areas. Installation of the modern devices in the vehicles for pollution control should be done and routine checking system should be implemented.

15. To reduce the pressure on the forest and the drudgery to which women are subjected due to use of smoke producing "chullas", an alternative fuel policy should be evolved and implemented. Large scale installation of solar panels in these areas would be beneficial.

16. Proper land use pattern should be done, keeping the socio-economic and ecological parameters in view.

The mountain ranges and hill areas of India have a crucial role to play in determining the climate and physiography of the country and are prime determinants of development of plain areas.

It is unquestionable that the hill areas of India, especially the Himalayas and the Nilgiris have major contributions in maintaining climatic and ecological balance in the country with their forests areas and watersheds. For a long time, these areas have not received their due emphasis on development issues.

The present work is the first ever socio-environmental study done at Lava and Rishop so far. Extensive investigations at other hill areas of North Bengal should be done so that the places could be highlighted for conservation in future.

\section{Acknowledgement}

Authors gratefully acknowledge Dr. Subarna Bhattacharyya, Coordinator, Department of Environmental Studies, Rabindra Bharati University and Dr. Aniruddha Mukhopadhyay, Head, Department of Environmental Science, University of Calcutta for their kind support and inspiration. Authors gratefully acknowledge Anup Thapa, Sujan Pradhan and Prakash Chettri, three young boys of Lava for their support and cooperation. All photographs were taken by Dr. Sayan Bhattacharya (Camera: Nikon D3200 and Nikon D5100 DSLR with Nikkor 18-105 mm. VR Lens and 55-300 mm. ED VR Lens).

\section{References}

[1] Government of West Bengal, India. North Bengal: Forestry operations and tourism. Accessed on $2^{\text {nd }}$ May, 2014. Accessed from: http://wb.gov.in/

[2] Wikipedia. Lava. Accessed on $2^{\text {nd }}$ May, 2014. Accessed from: http://en.wikipedia.org/wiki/Lava,_West_Bengal 
[3] North Bengal Development Department, Government of West Bengal. Welcome to Lava. Accessed on $2^{\text {nd }}$ May, 2014. Accessed from: http://wbnorthbengaldev.gov.in/HtmlPage/Lava.aspx

[4] About Rishyap. Accessed on $2^{\text {nd }}$ May 2014. Accessed from: http://www.rishyap.com/

[5] Das T. (2010). A note book on biodiversity of Neora Valley National Park. Department of forests, Government of West Bengal, India.

[6] Directorate of Forests, Government of West Bengal (1995). Tree improvement programme in silviculture (hills) division. Bulletin no. 4.

[7] Mallik J. K., Neora Valley-a new short listed world heritage site. Tiger paper 37(3) (2010) 12-16.

[8] Singhal N. (1999). Neora Valley National Park at a glance. Jalpaiguri: Divisional Forest Officer, Wildlife Division-II.

[9] Singhal N., A. Mukhopadhyay (1998). Management Plan of Neora Valley National Park, West Bengal for the period 1998-99 to 2007-08. Wildlife Circle, Govt. of West Bengal. 159 pp.

[10] Stattersfield A. J., Crosby M. J., Long A. J., Wege D. C. (1998). Endemic Bird Areas of the World: Priorities for Biodiversity Conservation. BirdLife Conservation Series No. 7 Bird Life International, Cambridge, U.K.

[11] Karmakar M., Ecotourism and its impact on the regional economy-A study of North Bengal, India. Tourismos 6(1) (2011) 251-270.

[12] Planning Commission, Government of India (2010). Report of the evaluation study on hill area development programme in Assam and West Bengal, pp. 1-145.

[13] UNESCO World Heritage Centre (2009). Neora Valley National Park. Accessed on $2^{\text {nd }}$ May, 2012, Accessed from: http://whc.unesco.org/en/tentativelists/5447

[14] IPCC. (2007). Climate Change 2007: Impacts, adaptation and vulnerability. Cambridge University Press, Cambridge, UK. 